\title{
Functional and Biochemical Parameters of Peptide Antigen Presentation ${ }^{1}$
}

\author{
David W. Thomas, ${ }^{2}$ Maxine J. Solvay, Gregg Hadley, ${ }^{3}$ \\ SORAYA BETANCOURT, ${ }^{4}$ SUSIE JUN, ${ }^{5}$ AND RODERICK NAIRN
}

\author{
Department of Microbiology and Immunology, University of Michigan \\ Medical School, Ann Arbor, Michigan 48109
}

Received October 23, 1987; accepted December 7, 1987

To understand the mechanism by which peptide antigens are processed and presented to $T$ cells, we examined the T-cell response to the 13-amino-acid peptide $\alpha$-melanocyte-stimulating hormone ( $\alpha$-MSH). To determine the fine specificity of T-cell recognition, T cells specific for $\alpha$ MSH, and genetically restricted by $\mathrm{I}-\mathrm{A}^{\mathrm{b} / \mathrm{d}}$, were challenged with different $\alpha$-MSH analogs and homologs. It was found that intact $\alpha$-MSH, including the blocked amino and carboxy termini of the native molecule, was required for T-cell responsiveness. Antigen-presenting cells (APC) could be briefly pulsed with $\alpha$-MSH and then present the $\alpha-\mathrm{MSH}$ antigenic determinant to T cells, indicating that the relevant antigen was retained by the APC. APC stimulatory capacity was dramatically reduced by aldehyde treatment of the APC, or by pulsing the APC with $\alpha$ MSH at low temperature. Efficient $\alpha$-MSH pulsing was also impaired by treatment of the APC with the carboxylic ionophore, monensin, but not by the lysosomotropic agents chloroquine and methylamine. In addition, isolated APC plasma membranes added to the T cells in the presence of soluble $\alpha$-MSH were not stimulatory. However, plasma membranes isolated from APC that had been previously pulsed with $\alpha$-MSH retained stimulatory activity for T-cell responses. The only detectable $\alpha$-MSH contained in these pulsed APC membranes was in an acidstable complex of higher molecular weight than native peptide. The amount of $\alpha$-MSH detected in the cellular membrane fraction isolated by density gradient sedimentation was also reduced by treatments that reduced the APC stimulatory capacity, such as pulsing at low temperature or in the presence of monensin. Taken together, these results suggest that processing of $\alpha-\mathrm{MSH}$ is unlike that heretofore described for other peptide antigens and seems to involve APC handling to form the stimulatory moiety presented on the APC surface. 1988 Academic Press, Inc.

\footnotetext{
' This work was supported by U.S. Public Health Service Grants AI-19273 (D.W.T.) and HL-33003 (R.N.), and Grant IM-464 (D.W.T.) from the American Cancer Society.

${ }^{2}$ To whorn correspondence should be addressed.

${ }^{3}$ Supported by U.S. Public Health Service Developmental Biology Training Grant HD07274-03.

${ }^{4}$ Supported by a Minority Graduate Fellowship Award from the National Science Foundation.

${ }^{5}$ Supported by funds from the Commitlee on Medical Student Research.
} 


\section{INTRODUCTION}

Over the past several years significant advances have been made in defining the mechanism of antigen processing by antigen-presenting cells (APC) ${ }^{6}$ for presentation to $T$ cells. First was the observation that native protein antigens needed to be catabolized to provide the appropriate antigenic determinants for T-cell responses $(1,2)$. In these cases protein catabolism occurred by lysosomal proteolysis to provide antigenic derivative peptides. This event is necessarily dependent on protein antigen internalization by the APC, and hence is blocked by treatments that block endocytosis (glutaraldehyde or paraformaldehyde) or lysosomal proteolysis (chloroquine or monen$\sin )(1,2)$. In addition, it was found that the preformed derivative peptide when added to APC did not require internalization and could be presented by fixed cells. The lack of a requirement for peptide antigen internalization was shown more elegantly by demonstrating that planar membranes containing immunoaffinity-purified Ia antigen could present the antigenic peptide to $T$ cells (3). These experiments suggested that peptide and Ia were all that was required for antigen presentation, and formally introduced the possibility that antigenic peptides may bind solely to Ia molecules to create the neoantigenic determinant recognized by $T$ cells. Indeed, recent evidence using equilibrium dialysis supports this proposal by showing that a small fraction of the Ia molecules in a purified Ia preparation binds peptide antigens with relatively low affinity $(4,5)$.

The latter results showing peptide antigen binding to Ia provides the long-anticipated result that the $T$-cell receptor binds a neoantigenic determinant comprised of elements from both Ia and foreign antigen together. While it is therefore reasonably clear that an antigen-Ia complex is recognized by the $T$ cell, the pathways that the antigen may take to eventually be bound by the Ia molecules are not clear. The simplest explanation is that exogenous peptide antigens bind directly to Ia on the APC surface to create the neoantigenic determinant. However, other reports suggest that the cellular reservoir of peptide antigen may involve an initial association with other non-Ia cellular structures (6-11). In addition, recent studies have shown that antigenic proteins expressed only intracellularly are somehow processed to provide antigenic peptides on the cell surface, presumably in association with MHC antigens (12, 13). Based on these results, it has been suggested that antigenic peptides and MHC molecules become associated in an intracellular location and that this newly formed complex is transported to the cell surface to be recognized by $T$ cells (14).

To better characterize the mechanism(s) of peptide antigen handling by APC, we used the 13-amino acid-peptide antigen, $\alpha$-melanocyte-stimulating hormone $(\alpha-$ $\mathrm{MSH}$ ), to investigate biochemical and functional aspects of APC processing. In this report we introduce this system and provide evidence suggesting that presentation of $\alpha-\mathrm{MSH}$ represents a novel pathway of peptide processing.

\footnotetext{
${ }^{6}$ Abbreviations used: ACTH, adrenocorticotrophic hormone; APC, antigen-presenting cell; $\alpha$-MSH, $\alpha$-melanocyte-stimulating hormone; IL-2, interleukin-2; Ia, I-region-associated antigen; SARS, specific antigen retention structures; FITC-fluoroscein isothiocyanate; FCS, fetal calf serum; HBSS, Hanks' buffered saline solution; PBS, phosphate-buffered saline; PMSF, phenylmethylsulfonylfluoride; SDS, sodium dodecyl sulfate; PPD, purified protein derivative; Con A, concanavalin A.
} 


\section{MATERIALS AND METHODS}

Animals. All mice used in these experiments were bred and maintained in the animal facility at the University of Michigan Medical School.

Peptide antigens. All synthetic peptides were purchased from Vega Biochemicals (Tucson, AZ). The primary structure of $\alpha$-MSH (a derivative peptide comprising the first 13 residues of adrenocorticotrophic hormone, ACTH) is as follows:

$$
\mathrm{AcSer}^{1}-\mathrm{Tyr}^{2}-\mathrm{Ser}^{3}-\mathrm{Met}^{4}-\mathrm{Glu}^{5}-\mathrm{His}^{6}-\mathrm{Phe}^{7}-\mathrm{Arg}^{8}-\mathrm{Trp}^{9}-\mathrm{Gly}^{10}-\mathrm{Lys}^{11}-\mathrm{Pro}^{12}-\mathrm{Val}^{13}-\mathrm{NH}_{2}
$$

Fluorescein isothiocyanate (FITC)- $\alpha$-MSH was made by incubation of $\alpha$-MSH with

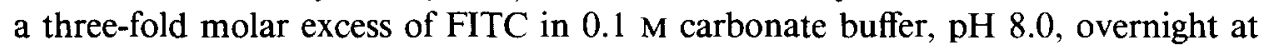
room temperature, and the free FITC was removed by chromatography over Sephadex G-10 (Pharmacia Fine Chemicals, Piscataway, NJ) in phosphate-buffered saline, $\mathrm{pH}$ 7.2. Under these conditions only the Lys ${ }^{11}$ can be conjugated.

Cell lines. Mice were immunized with $100 \mu \mathrm{g}$ of $\alpha$-MSH in complete Freund's adjuvant (Difco Laboratories, Detroit, MI); 10 days later the draining lymph nodes were removed and the immune T cells $\left(2.5 \times 10^{6} / \mathrm{ml}\right)$ stimulated by culture with 8 $\mu \mathrm{g} / \mathrm{ml}$ of $\alpha$-MSH in RPMI 1640 medium (M. A. Bioproducts, Walkersville, MD) containing $300 \mu \mathrm{g} / \mathrm{ml}$ glutamine (KC Biological, Lenexa, KS), $5 \times 10^{-5} \mathrm{M}$ 2-mercaptoethanol (Bio-Rad Laboratories, Richmond, CA), and 10\% heat-inactivated fetal calf serum (FCS, Hyclone Laboratories, Logan, UT) for 3 days at $37^{\circ} \mathrm{C}$ in $5 \% \mathrm{CO}_{2}$ in air. The blast cells were harvested by centrifugation on Ficoll-Hypaque (Sigma Chemical Co., St. Louis, MO) and either subcloned by limiting dilution in microtiter wells containing $\alpha$-MSH and fresh irradiated syngeneic spleen cells, or expanded and fused with BW5147 cells by established procedures (15, 16). Hybridomas were screened for production of interleukin-2 (IL-2) specifically upon stimulation with $\alpha$ $\mathrm{MSH}$ and $(\mathrm{C} 57 \mathrm{BL} / 6 \times \mathrm{BALB} / \mathrm{C}) \mathrm{F}_{1}$ spleen cells, and positive hybrids subcloned to produce stable lines, of which $27 \mathrm{E} 11$ is representative.

Since all T cell responses to $\alpha$-MSH were genetically restricted by I-A ${ }^{\text {b/d }}$, LB27.4 cells, a hybrid B-cell line expressing Ia ${ }^{\mathrm{b} / \mathrm{d}}(17)$, were used as APC in most experiments, and were a generous gift from Dr. D. Shapiro of the University of Michigan Medical School. The monoclonal antibodies were obtained as culture supernatant fluids from hybridomas obtained from the American Type Culture Collection (Rockville, MD) and include 10.2.16, anti-IA ${ }^{k}$ (18); MKD6, anti-IA ${ }^{d}$ (16); and M5/114.15.2, anti$\mathrm{IA}^{\mathrm{b}, \mathrm{d}, \mathrm{q}} \mathrm{IE}^{\mathrm{d}, \mathrm{k}}(19)$.

APC treatment. APC were pulsed by incubation with $200 \mu \mathrm{g} / \mathrm{ml}$ of $\alpha-\mathrm{MSH}$ for 2 hr (or overnight in some experiments) at $37^{\circ} \mathrm{C}$ (or $4^{\circ} \mathrm{C}$ in some experiments) in serumfree medium, then washed three times in Hanks' buffered saline solution (HBSS, KC Biological) to remove free peptide. In some experiments using monensin, chloroquine, and methylamine, the cells were preincubated with the agent at the concentrations indicated in the table $30 \mathrm{~min}$ before adding $\alpha-\mathrm{MSH}$, and left in culture for the 2 hr pulse. For glutaraldehyde fixation, cells were washed in phosphate-buffered saline (PBS, pH 7.2) and treated by mixing for $15 \mathrm{sec}$ with the indicated concentration of glutaraldehyde in PBS. The reaction was terminated by adding excess PBS containing $0.1 \%$ glycine (Sigma) and the cells were washed three times before being used.

Preparation of plasma membranes. Antigen-pulsed or unpulsed LB27.4 cells were washed three times in HBSS and resuspended in HBSS containing $1 \mu \mathrm{g} / \mathrm{ml}$ of phenyl- 
methylsulfonylfluoride (PMSF, Sigma); then the cells were disrupted in a cell disrupter (Stansted Fluid Power Ltd., Essex, England) using an aperture setting that sheared only the plasma membranes from the surface of the cells while leaving the nucleus and much of the cytoplasm intact, according to the method of Crumpton and Snary (20). The sheared cells were centrifuged at $450 \mathrm{~g}$ for $10 \mathrm{~min}$ at $4^{\circ} \mathrm{C}$ to remove nuclei and intact cells; then the supernantant fluid was centrifuged at $3650 \mathrm{~g}$ for $15 \mathrm{~min}$ at $4^{\circ} \mathrm{C}$ to pellet subcellular organelles. The resultant supernatant fluid was centrifuged at $31,000 \mathrm{~g}$ for $40 \mathrm{~min}$, and the resultant crude plasma membrane pellet was resuspended in sterile PBS and immediately used for addition to culture or stored at $-70^{\circ} \mathrm{C}$.

To determine the cellular location of the radioactive peptide, LB27.4 cells were pulsed with $10 \mu \mathrm{Ci}$ of ${ }^{125} \mathrm{I}-\alpha-\mathrm{MSH}$ for $2 \mathrm{hr}$ at $37^{\circ} \mathrm{C}$ in $4 \mathrm{ml}$ of RPMI 1640 containing $10 \mu \mathrm{g} / \mathrm{ml}$ of cycloheximide. In experiments examining the effects of inhibitors, 50 $\mu M$ chloroquine or monensin was added 30 min prior to the addition of peptide. The pulsed cells were washed three times in HBSS to remove non-cell-associated peptide, and then resuspended in ice-cold HBSS containing $10 \mu \mathrm{g} / \mathrm{ml}$ of PMSF. The cells were disrupted by two passes through the Stansted cell disrupter set at an aperture that sheared all of the outer membranes and cytoplasm from the cells. Nuclei were removed by centrifugation at $450 \mathrm{~g}$ for $10 \mathrm{~min}$ at $4^{\circ} \mathrm{C}$. The postnuclear cell lysate was run over a Percoll gradient according to the method of Merion and Poretz (21). Briefly, the cell lysate $(12 \mathrm{ml})$ was layered over a $30 \%$ Percoll (Pharmacia) solution $(22 \mathrm{ml})$ that had previously been layered over $3 \mathrm{ml}$ of a $60 \%$ sucrose preparation. The tubes were centrifuged in a Beckman Ti55.2 fixed-angle rotor at $40,000 \mathrm{~g}$ for $60 \mathrm{~min}$ at $4^{\circ} \mathrm{C}$. Fractions $(1 \mathrm{ml})$ were collected from the bottom and the ${ }^{125} \mathrm{I} \mathrm{cpm}$ in each fraction determined in a gamma counter. Density standard beads (Pharmacia) were added to each tube to determine the density assignments of the various fractions. Location of the plasma membrane fraction was determined from lysate of cells that were pulsed for $30 \mathrm{~min}$ at $4^{\circ} \mathrm{C}$ with ${ }^{125} \mathrm{I}$-concanavalin $\mathrm{A}$ (Con A, New England Nuclear, Boston, MA) and washed to leave only plasma membrane-bound lectin. It should be pointed out that the plasma membrane fraction identified in this manner also contains Golgi and lysosomal membranes (21) and is therefore referred to as the cellular membrane fraction in the remainder of this report.

Chromatographic analysis of radioactive $\alpha-M S H . \alpha-\mathrm{MSH}$ was radioiodinated with ${ }^{125} \mathrm{I}$ using Iodo-beads according to an established protocol (Bio-Rad) to yield ${ }^{125} \mathrm{I}-\alpha$ $\mathrm{MSH}$ with sp act of 5.3 to $6.1 \mu \mathrm{Ci} / \mu \mathrm{g}$ in various preparations. Intact cells or isolated plasma membranes were incubated at $37^{\circ} \mathrm{C}$ for $4 \mathrm{hr}$, or overnight in some experiments, and then the cells washed and solubilized in $0.5 \%$ Nonidet P-40 as described elsewhere (6). The soluble preparations were made to $10 \%$ acetic acid and chromatographed over a $2.5 \times 50-\mathrm{cm}$ column of Sephadex G-25 Superfine (Pharmacia), and the ${ }^{125}$ I cpm of each collected fraction determined as before (6).

$T$-Cell stimulation culture and assay for IL-2 production. $\alpha$-MSH-specific T cells $\left(2 \times 10^{5} /\right.$ well $)$ were cultured with $10^{5} \mathrm{LB} 27.4$ cells, or $10^{6}$ spleen cells with or without different concentrations of peptide antigen as indicated under Results. After $20 \mathrm{hr}$ of culture the supernatant fluids were removed and assayed for IL-2 with the IL-2dependent HT-2 cell line (a generous gift from Dr. E. Shevach, NIH) as described elsewhere (16). The greatest dilution of supernatant fluid maintaining more than $90 \%$ 
HT-2 viability was the end point scored, and the reciprocal of this dilution is expressed as IL-2 units per $\mathbf{m l}$.

\section{RESULTS}

\section{Specificity of T-Cell Responses to $\alpha-M S H$}

In our previous work we have studied the cellular immune response to several different peptide systems to better understand the molecular basis for antigen presentation to T cells. Most of this work has used guinea pigs because of the ease of generating antipeptide cellular responses in that species. However, the guinea pig model is limited in not having available homogeneous T-cell and APC lines necessary to better define the biochemical basis of antigen recognition. It was therefore necessary to establish a peptide antigen system in mice to better analyze antigen processing and presentation using homogeneous cell lines. We chose $\alpha$-MSH as the model antigen for several reasons: synthetic $\alpha$-MSH could be purchased at a reasonable cost; synthetic analogs and homologs were also available; the peptide could be radiolabeled; it was relatively hydrophilic; and it was potentially interesting with regard to the response of the immune system to neuropeptides. In exploratory studies $\alpha$-MSH was tested for antigenicity by injection into mice of different $\mathrm{H}-2$ haplotypes $\left(\mathrm{b}, \mathrm{d}, \mathrm{k}\right.$, and $\left.\mathrm{b} \times \mathrm{d} \mathrm{F}_{1}\right)$. By in vitro lymph node lymphocyte proliferative responses, it was found that only (b $\times$ d) $\mathrm{F}_{1}$ mice were responders to $\alpha$-MSH, and the other strains tested were unresponsive by this criterion. T cells from $\alpha$-MSH-immunized $F_{1}$ mice were also hybridized and $\alpha$-MSH-specific IL-2-producing hybridomas identified: one of these with representative specificities, 27E11, was used for further studies as described in this report.

The peptide and MHC specificities of the 27E11 T-cell response are summarized in Table 1. It is clear that the response to $\alpha$-MSH requires the intact native peptide; shortened or lengthened peptides do not provide the relevant antigenic determinant. In addition, the substitution of $\mathrm{Nle}^{4}$ greatly reduces antigenicity, which is further reduced by the additional substitution of $\mathrm{D}-\mathrm{Phe}^{7}$, and antigenicity is destroyed by modifying Lys ${ }^{11}$. This fine specificity of $27 \mathrm{E} 11$ is the same as found for polyclonal Tcell responses to $\alpha$-MSH (data not shown). Another interesting feature of $\alpha-\mathrm{MSH}$ antigenicity is that both termini are blocked in the native molecule, and that unblocking either end greatly reduces antigenicity for $27 \mathrm{E} 11$ responses (Table 1 , lines 4 and 5 ). This, together with the requirement for intact $\alpha$-MSH for antigenicity, strongly suggests that the relevant antigenic determinant is only present on unaltered native $\alpha-\mathrm{MSH}$. This is an important consideration, as will become evident later. Also shown in Table 1 is that the response of $27 \mathrm{E} 11$ is genetically restricted by a recombinant Ia molecule, $\mathrm{I}-\mathrm{A}^{\mathrm{b} / \mathrm{d}}$, as found for all $\mathrm{T}$-cell responses to this antigen, and is inhibited by antibodies directed against the $\mathrm{A}_{\beta}^{\mathrm{d}}$ chain.

\section{Cellular Fate of $\alpha-M S H$}

To ensure that the $\alpha$-MSH system was suitable for examining antigen presentation by APC, we first determined that $\alpha$-MSH-pulsed APC (LB27.4 cells or H-2 ${ }^{\text {b/d }}$ spleen cells) stimulated T cclls (Tablc 1). It is clear that $\alpha$-MSH-pulsed cells are highly stimulatory, but the IL-2 titers are often slightly less than those obtained from cultures with soluble $\alpha$-MSH continuously present, as can be seen in some of the following tables. 
TABLE 1

Fine Specificity of T-Cell Responses to $\alpha$-MSII

\begin{tabular}{|c|c|c|c|}
\hline Peptide antigen & Antigen-presenting cell & & $\begin{array}{c}\text { Relative IL-2 } \\
\text { response }\end{array}$ \\
\hline$\alpha-\operatorname{MSH}(1-13)$ & LB27.4 & & +++ \\
\hline $\mathrm{Nle}^{4}-\alpha-\mathrm{MSH}$ & LB27.4 & & + \\
\hline $\mathrm{Nle}^{4}, \mathrm{D}-\mathrm{Phe}^{7}-\alpha-\mathrm{MSH}$ & LB27.4 & & - \\
\hline Des-AcSer ${ }^{1}-\alpha$-MSH & LB27.4 & & \pm \\
\hline Val-OH ${ }^{13}-\alpha-\mathrm{MSH}$ & LB27.4 & & \pm \\
\hline FITC-Lys ${ }^{11}-\alpha-$ MSH & LB27.4 & & - \\
\hline$\alpha-\mathrm{MSH} / \mathrm{ACTH}(1-10)$ & $\mathrm{LB} 27.4$ & & - \\
\hline $\operatorname{ACTH}(1-24)$ & LB27.4 & & - \\
\hline$\alpha$-MSH & C57BL/6 (H-2 $\left.{ }^{\mathrm{b}}\right)$ spleen & & - \\
\hline$\alpha-\mathrm{MSH}$ & BALB/c $\left(\mathrm{H}-2^{\mathrm{d}}\right)$ spleen & & - \\
\hline$\alpha$-MSH & $\mathrm{A} / \mathrm{J}\left(\mathrm{H}-2^{\mathrm{k} / \mathrm{d}}\right)$ spleen & & - \\
\hline$\alpha$-MSH & $(\mathrm{C} 57 \mathrm{BL} / 6 \times \mathrm{BALB} / \mathrm{c}) \mathrm{F}_{1}$ spleen & & +++ \\
\hline$\alpha$-MSH & $\mathrm{LB} 27.4$ & $\left(\operatorname{tanti}-\mathrm{IA}^{\mathrm{k}}\right)$ & +++ \\
\hline$\alpha$-MSH & LB27.4 & $\left(\operatorname{tanti}-\mathrm{IA}^{\mathrm{d}}\right)$ & \pm \\
\hline$\alpha-\mathrm{MSH}$ & LB27.4 & $\left(+\operatorname{anti}-\mathrm{IA}^{\mathrm{b}, \mathrm{d}, \mathbf{q}}, \mathrm{IE}^{\mathrm{d}, \mathrm{k}}\right)$ & - \\
\hline $\begin{array}{l}\text { LB27.4 pulsed with } \alpha \text {-MSH } \\
(\mathrm{C} 57 \mathrm{BL} / 6 \times \mathrm{BALB} / \mathrm{c}) \mathrm{F}_{1} \\
\text { spleen cells pulsed with }\end{array}$ & & & ++ \\
\hline$\alpha-\mathrm{MSH}$ & & & ++ \\
\hline
\end{tabular}

Note. The relative IL-2 responses shown are a summary of a number of different experiments compiled into a single table for ease of presentation. While similar responses were observed for both $\alpha$-MSH-specific T-cell clones and hybridomas, the results depicted are for the T-cell hybridoma $27 \mathrm{E} 11\left(2 \times 10^{5}\right.$ cells/well $)$ stimulated with peptide with either the LB27.4 cell line $\left(10^{5}\right.$ cells/well $)$ or spleen cells $\left(10^{6}\right.$ cells/well $)$ as indicated. For antigen specificity, each peptide was tested in serial dilutions with the highest concentration being $20 \mu \mathrm{g} / \mathrm{well}$. The response of $27 \mathrm{E} 11$ is at its peak at around $2 \mu \mathrm{g} / \mathrm{well}$, and those weak responses shown for the peptide analogs were observed only at $20 \mu \mathrm{g} / \mathrm{well}$, In some experiments APC were pulsed with $\alpha$ MSH for 2 to $18 \mathrm{hr}$ in serum-free medium and washed to remove unbound peptide as described under Materials and Methods. All monoclonal anti-Ia antibodies (anti-IA ${ }^{\mathrm{k}}, 10.2 .16$; anti-IA ${ }^{\mathrm{d}}$, MKD6; and anti$\left.\mathrm{IA}^{\mathrm{b}, \mathrm{d}, \mathrm{q}}, \mathrm{IE}^{\mathrm{d}, \mathrm{k}}, \mathrm{M} 5 / 114.15 .2\right)$ were added at a $10 \%$ final volume of antibody-containing culture supernatant fluids. The IL-2 titers were scored visually hy the highest dilution that maintained viability of the IL-2dependent cell line HT-2. The relative responses are scored as follows: +++ , IL-2 titers of $640-2560$; ++ , IL-2 titers of $160-320 ;+$, IL-2 titers $40-80 ; \pm$, IL-2 titers of $20 ;-$, IL-2 titers of $<20$.

To examine the cellular fate of the peptide the APC (LB27.4 cells) were incubated with radiolabeled $\alpha$-MSH and chromatographed to resolve the cell-associated radioactivity. As shown in Fig. 1 A, most of the LB27.4 cell-associated $\alpha$-MSH is degraded to fragments migrating at fractions 60-65 (and also at fractions 75-80 in some experiments, e.g., as shown in Fig. 2); a small amount of native $\alpha$-MSH running at fractions $52-57$ is detectable in some experiments after a 4-hr incubation. There is also a significant amount of $\alpha$-MSH ( 5 to $15 \%$ of the total cell-associated amount) migrating with an apparent molecular weight greater than the native peptide in the void volume of the column at positions 23-25 (Peak A), similar to that previously observed with other peptides incubated with guinea pig cells (6). It should be pointed out that this Peak A material does not necessarily refer to a single molecular species, since many cellular proteins are contained in the void volume. As we have shown before, forma- 

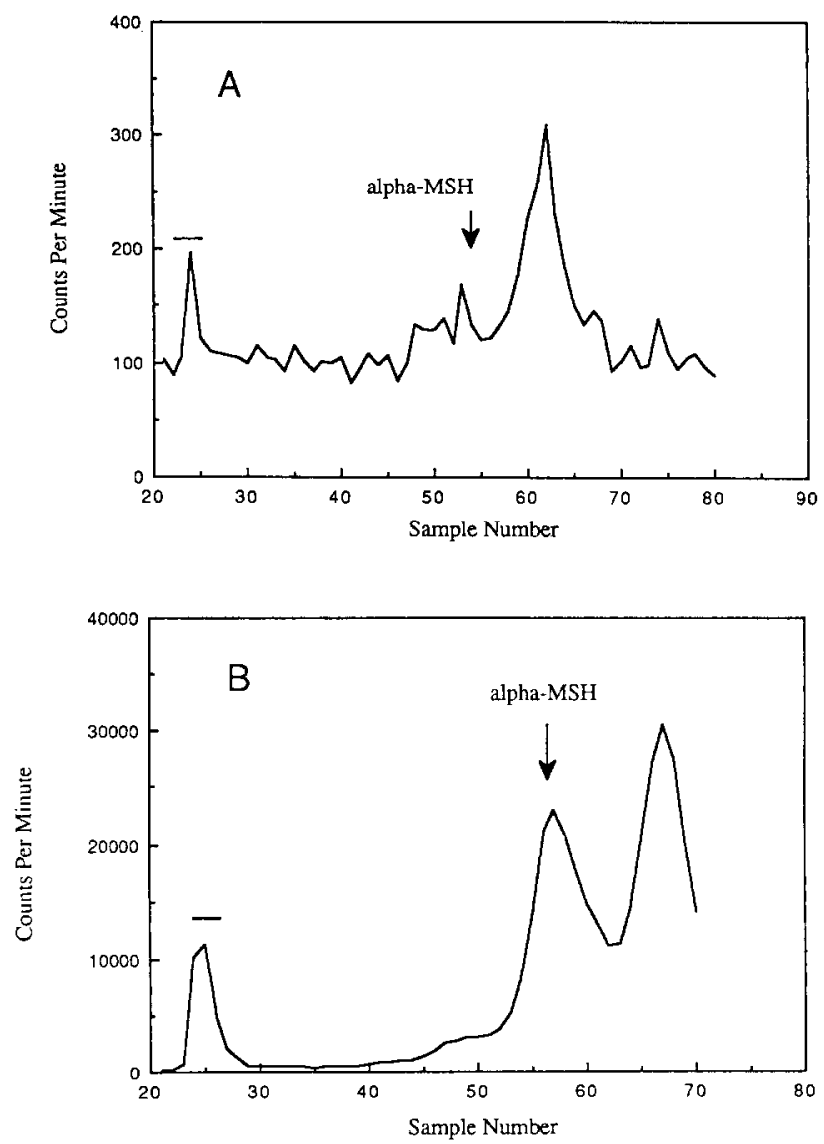

FIG. 1. Formation of a higher molecular weight form of $\alpha$-MSH by LB27.4 cells and plasma membranes. LB27.4 cells $\left(5 \times 10^{6}\right.$, panel A) or isolated plasma membranes $\left(80 \times 10^{6}\right.$ cell equivalents, panel B) were incubated with ${ }^{125} \mathrm{I}-\alpha-\mathrm{MSH}(5 \mu \mathrm{Ci} / \mathrm{ml})$ in serum-free medium for $4 \mathrm{hr}$ at $37^{\circ} \mathrm{C}$, and the cells were washed to remove non-cell-associated peptide. Both the cells and membranes were solubilized and the soluble material was made to $10 \%$ acetic acid and chromatographed on Sephadex G-25, as described under Materials and Methods. The void volume of the column is around fraction 25 (shown by migration of cytochrome $C$ as indicated by the bar), and native $\alpha-\mathrm{MSH}$ migrates at approximately fraction 55 . Note that there is a scale difference between panels A and B and that the migration of $\alpha$-MSH is the same in both experiments. The material eluting with the void volume is called Peak A.

tion of these Peak A complexes is peptide-specific, and these complexes are not produced by all cell types, thereby ruling out that the Peak $A$ material represents nonspecific trapping under the conditions used to run the column $(6,22)$. Indeed, acidic conditions were employed to enhance peptide solubility and avoid aggregation.

These latter results indicate that the $\alpha$-MSH contained in Peak A may represent peptide stably bound to some higher molecular weight cellular component. To determine whether these binding structures were located in the membrane, plasma membranes were isolated from LB27.4 cells and incubated with radiolabeled $\alpha-\mathrm{MSH}$. As we found before for other peptide antigens $(6,7)$, complexes containing $\alpha$-MSH can be detected in association with the plasma membrane, as shown in Fig. 1B. It is also 

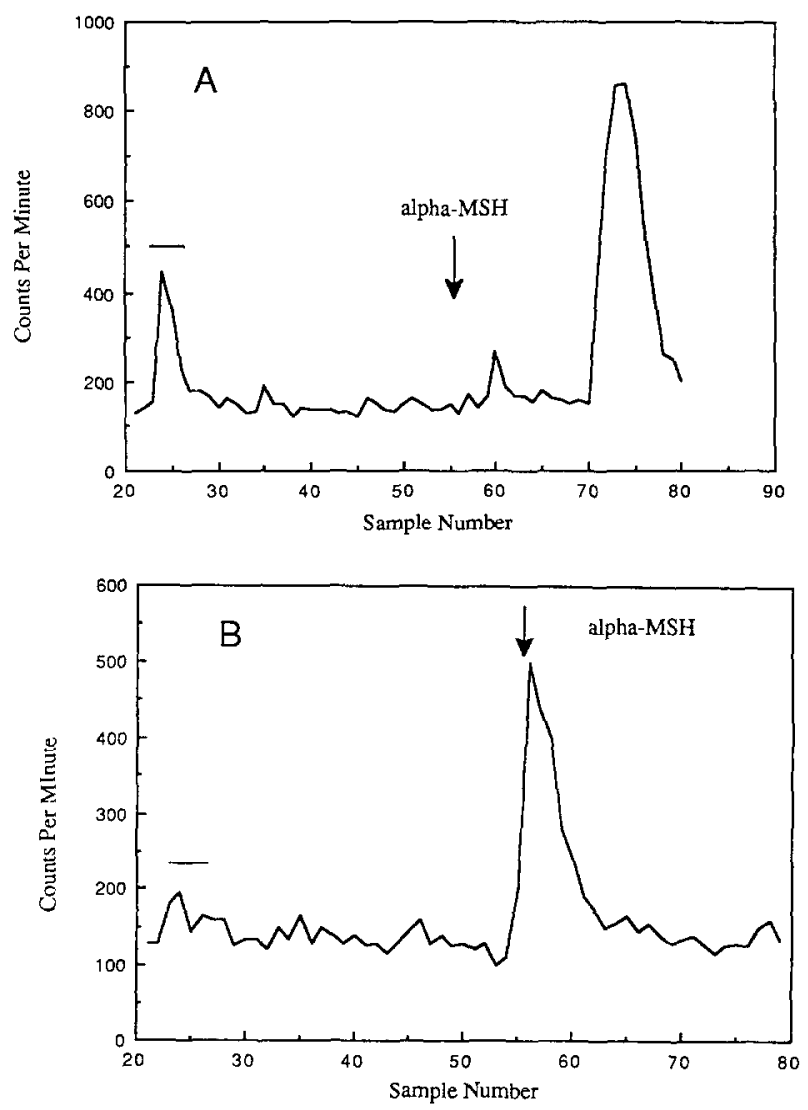

FIG. 2. The nature of $\alpha$-MSH contained in the Peak A complex. LB27.4 cells $\left(5 \times 10^{6}\right)$ were incubated with ${ }^{125} \mathrm{I}-\alpha$-MSH as described in the legend for Fig. 1. The $\alpha$-MSH-containing Peak A complex was isolated by chromatography on Sephadex G-25 as before and an aliquot used to determine the cpm of each fraction (panel A). The fractions containing the Peak A (25-27) were pooled, lyophilized, then redissolved in buffer containing 1\% SDS, boiled for $5 \mathrm{~min}$, and rechromatographed on Sephadex G-25 as before (panel B). Note that there is a scale difference between panels A and B and that $\alpha$-MSH migrates at a similar position in both experiments.

apparent by the presence of a large peak at positions 65-70 that the membrane preparations contain proteases that can degrade $\alpha$-MSH.

As shown in Table 1, it appears that the intact native $\alpha-\mathrm{MSH}$ peptide is required for antigenicity. To determine if the radioactivity in the Peak A material was still associated with some form of $\alpha-\mathrm{MSH}$, the Peak A made by LB27.4 cells was isolated by chromatography on Sephadex G-25, as shown in Fig. 2A. In this particular experiment the degraded peptide migrated more slowly than usual, but this did not influence the isolation of the complex that migrated in the void volume at positions 2427. The isolated Peak A was then boiled in sodium dodecyl sulfate (SDS) to dissociate the peptide component and rechromatographed to identify the size of the $\alpha$-MSH contained in the complex. As shown in Fig. 2B, all of the peptide was released from the complex upon boiling in SDS, suggesting a noncovalent association in this case, 
TABLE 2

T-Cell Stimulation by Plasma Membranes from $\alpha$-MSH-Pulsed APC

\begin{tabular}{lrr}
\hline & \multicolumn{2}{c}{ IL-2(Units/ml) } \\
\cline { 2 - 3 } \multicolumn{1}{c}{ Additions to culture } & Expt 1 & Expt 2 \\
\hline LB27.4 cells & $<20$ & $<20$ \\
LB27.4 cells $+2 \mu \mathrm{g}$ soluble $\alpha$-MSH & 1280 & 1280 \\
LB27.4 cells + anti-IA & ND & 80 \\
LB27.4 cells pulsed with $\alpha$-MSH & 320 & ND \\
LB27.4 plasma membranes & $<20$ & $<20$ \\
LB27.4 plasma membranes $+2 \mu$ g soluble $\alpha$-MSH & $<20$ & $<20$ \\
Plasma membranes from $\alpha$-MSH-pulsed LB27.4 cells & 40 & 160 \\
Plasma membranes from $\alpha$-MSH-pulsed LB27.4 cells + anti-IA & ND & $<20$ \\
\hline
\end{tabular}

Note. T cells $\left(2 \times 10^{5} 27 \mathrm{E} 11\right)$ were cultured with $10^{5} \mathrm{LB} 27.4$ cells with or without $\alpha$-MSH and MKD6 anti-Ia ( $10 \%$ final volume of antibody-containing supernatant fluid) as indicated in the table. Plasma membranes were isolated from unpulsed LB27.4 cells or LB27.4 cells that had been pulsed overnight with 150 $\mu \mathrm{g} / \mathrm{ml}$ (Expt 1) or $200 \mu \mathrm{g} / \mathrm{ml}$ (Expt 2) of $\alpha$-MSH and washed to remove non-cell-associated peptide. The isolated plasma membrane preparations were added to $27 \mathrm{E} 11 \mathrm{~T}$ cells in varying concentrations and the results are shown for $6 \times 10^{6}$ cell equivalents. Other experiments (not shown) using soluble $\alpha$-MSH at concentrations up to $20 \mu \mathrm{g}$ with unpulsed LB membranes failed to cause T-cell stimulation. The IL-2 units were determined as described under Materials and Methods. ND, not determined.

and migrated as a single pcak in a position similar to that of native $\alpha$-MSH. Thus, the Peak A complex contains a form of $\alpha$-MSH that appears homogeneous and does not contain a variety of degraded peptide fragments. Although the migration of the released peptide migrates in a position similar to that of native $\alpha$-MSH, these conditions of fractionation may not discriminate subtle modifications of the released peptide. Of interest, we have found with other peptide antigens that some of the Peak $A$ complex ( 10 to $50 \%$ ) is resistant to repeated boiling in SDS, indicating covalent bonding (6), which may involve the carboxyl terminus (7, S. Jun, unpublished observations).

\section{T-Cell Stimulation by Isolated APC Plasma Membranes}

Since in most peptide antigen systems no antigen processing is apparent, $T$ cells can be directly stimulated by peptide antigen in the presence of Ia-containing membranes. To determine if this were also true in the $\alpha-\mathrm{MSH}$ system, membranes were isolated from LB27.4 cells and examined for stimulation of 27E11 T cells in the presence of $\alpha$-MSH. To our surprise, APC membranes alone failed to stimulate in the presence of peptide (Table 2). Thus, presentation of $\alpha$-MSH is apparently different than in other peptide antigen systems examined to date. Since we knew that $\alpha$ MSH-pulsed LB27.4 cells were stimulatory, which at some point involves recognition of antigen on the APC surface, we decided to isolate plasma membranes from LB27.4 cells that had been previously pulsed with $\alpha$-MSH, and therefore likely to contain the relevant antigen. As shown in Table 2, plasma membranes isolated from $\alpha$-MSHpulsed LB27.4 cells directly stimulated the 27E11 T cells, which were inhibited by anti-IA ${ }^{\mathrm{d}}$ antibodies, whereas membranes from unpulsed cells added with soluble $\alpha$ - 


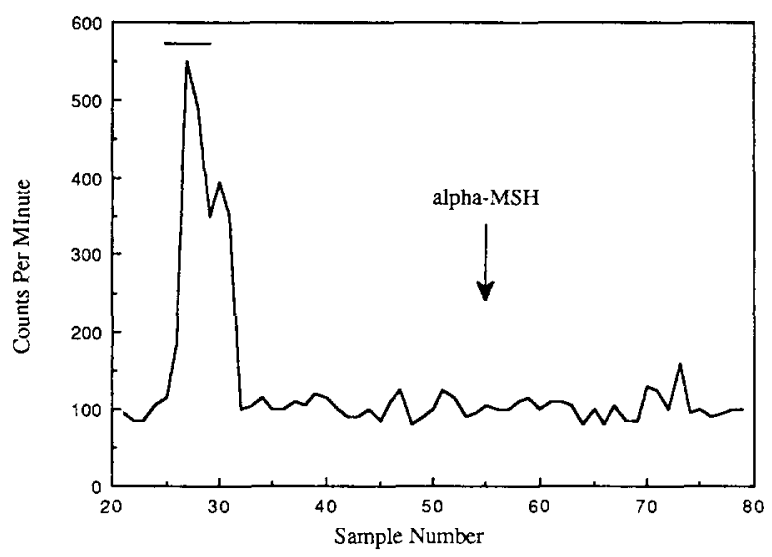

FIG. 3. The nature of $\alpha$-MSH contained in the plasma membranes of $\alpha$-MSH-pulsed LB27.4 cells. LB27.4 cells $\left(40 \times 10^{6}\right)$ were incubated overnight with ${ }^{125} \mathrm{I}-\alpha$-MSH in parallel with the cells used in Table 2, Experiment 2. The plasma membranes were isolated from the pulsed cells and solubilized, and the soluble material was chromatographed on Sephadex G-25 as before. All of the ${ }^{125} \mathrm{I} \mathrm{cpm} \mathrm{were} \mathrm{detected} \mathrm{in}$ the soluble fraction of the membrane preparation.

MSH were nonstimulatory. The fact that membranes from unpulsed cells were routinely nonstimulatory in the presence of soluble peptide rules against the stimulation with membranes from antigen-pulsed cells being due to a few contaminating viable cells, which would further be resistant to freeze-thawing. Though readily apparent, the stimulation by membranes from pulsed cells was significantly less than that by intact pulsed cells from which the membranes were derived on a cell-equivalent basis ( 320 titer for $10^{5}$ pulsed intact cells, versus titers of 40 to 160 for $6 \times 10^{6}$ cell equivalents of membranes). Much of this difference is probably due to the fact that the membrane isolation procedure is not $100 \%$ efficient, and that at least half of the membranes are present as nonfunctional inside-out vesicles.

To determine in what form $\alpha$-MSH existed in stimulatory membranes from pulsed APC, LB27.4 cells were incubated with radiolabeled $\alpha$-MSH under conditions identical to those in the functional experiment described above, and the plasma membranes of these cells were prepared at the same time as the pulsed membranes used for functional assessment (Table 2, Experiment 2). The isolated membranes containing the radiolabeled $\alpha$-MSH were solubilized (all radioactivity was soluble) and chromatographed as before. As shown in Fig. 3, all of the membrane-associated $\alpha$-MSH was associated with a higher molecular weight moiety, and there was no detectable free peptide. The apparent split in the Peak A observed in this particular experiment is due to slightly lower cpm in one fraction, which we do not consider to be significant and was not observed in many other experiments.

\section{Evidence for $\alpha$-MSH Processing by APC}

One explanation for the results with unpulsed and $\alpha$-MSH-pulsed membranes described above is that the creation of a stimulatory form of $\alpha$-MSH requires cellular processing. In most other systems with protein antigens, this involves antigen inter- 
TABLE 3

Effect of Aldehyde Fixation on $\alpha$-MSH Presentation

\begin{tabular}{lcc}
\hline \multicolumn{1}{c}{ APC treatment } & T cells & IL-2 (Units/ml) \\
\hline Untreated & $27 \mathrm{E} 11$ & $<20$ \\
Untreated $+5 \mu$ g soluble $\alpha$-MSH & $27 \mathrm{E} 11$ & 640 \\
$0.1 \%$ Glutaraldehyde treated & $27 \mathrm{E} 11$ & $<20$ \\
$0.1 \%$ Glutaraldehyde treated $+5 \mu \mathrm{g}$ soluble $\alpha$-MSH & $27 \mathrm{E} 11$ & 40 \\
Untreated & $8 \mathrm{~B} 2$ & $<20$ \\
Untreated $+10 \mu$ g soluble PPD & $8 \mathrm{~B} 2$ & 640 \\
$0.1 \%$ Glutaraldehyde treated $+10 \mu \mathrm{g}$ soluble PPD & $8 \mathrm{~B} 2$ & 640 \\
\hline
\end{tabular}

Untreated or glutaraldehyde treated LB 27.4 cells were added to culture with $27 \mathrm{E} 11\left(\alpha-\mathrm{MSH} / \mathrm{IA}^{\mathrm{b} / \mathrm{d}}\right.$ specific) or $8 \mathrm{~B} 2$ (PPD/1A ${ }^{\mathrm{d}}$ specific) with soluble antigen as indicated in the Table. Representative IL-2 titers from one experiment are shown, and similar results have been obtained in six other experiments.

nalization (blocked by aldehyde fixation) and catabolism by lysosomal enzymes (blocked by chloroquine and monensin). To test this, a variety of treatments were used that either inhibited cellular internalization or prevented intracellular transport and acidification, as have been used by many others examining antigen processing $(1,2)$. First, glutaraldehyde-treated LB27.4 cells showed a greatly reduced ability to present $\alpha$-MSH when compared to untreated APC (Table 3). However, these same fixed APC were able to efficiently present the antigen purified protein derivative (PPD) to PPD-specific T cells. In previous studies we have found that PPD did not require $\mathrm{APC}$ internalization and intracellular processing for presentation to $\mathrm{T}$ cells by A20 and LB27.4 cells (16). These findings suggest that the most efficient presentation of $\alpha$-MSH requires peptide internalization by the APC. Consistent with this is that pulsing the APC with $\alpha-\mathrm{MSH}$ at $4^{\circ} \mathrm{C}$, which also impairs membrane mobility and antigen internalization, is much less efficient than pulsing at $37^{\circ} \mathrm{C}$ (IL-2 titers of $<20-40$ at $4^{\circ} \mathrm{C}$ versus $160-320$ at $37^{\circ} \mathrm{C}$ ).

For most protein antigens, cellular internalization is required for lysosomal degradation of the protein to form antigenic peptides. This event can be blocked by agents (chloroquine, methylamine, and monensin) that interfere with intracellular trafficking and lysosomal proteolysis. This internalization-proteolysis step is not needed for antigenic peptides thus far described (1-5) and, indeed, seemed unlikely to be involved in $\alpha$-MSH processing as discussed above. It was therefore not surprising that chloroquine and methylamine had no effect on the antigenicity of $\alpha$-MSH pulsed LB27.4 cells, as shown in Table 4. In our hands, treatment with these agents at similar concentrations efficiently blocks processing of protein antigens by some APC (15, unpublished observations). However, we were surprised to find that monensin at $10 \mu M$ or greater dramatically reduced $\alpha-\mathrm{MSH}$ stimulation when present during the antigen pulse. LB27.4 cells treated with monensin and cultured to allow recovery presented $\alpha$-MSH efficiently, suggesting that monensin inhibition is not generally toxic (data not shown).

To determine the reason for the reduction in stimulatory capacity of APC pulsed with $\alpha-\mathrm{MSH}$ at $4^{\circ} \mathrm{C}$ or in the presence of monensin, we examined the cellular compartmentalization of radiolabeled $\alpha$-MSH under these conditions using density gradi- 
TABLE 4

Effect of Inhibitors on $\alpha$-MSH Presentation

\begin{tabular}{cc}
\multicolumn{1}{c}{ APC treatment } & IL-2 (Units/ml) \\
\hline Unpulsed & $<20$ \\
$\alpha$-MSH-pulsed with no inhibitor & 160 \\
+ Monensin, $3 \mu M$ & 160 \\
+ Monensin, $30 \mu M$ & 20 \\
+Monensin, $100 \mu M$ & $<20$ \\
+Chloroquine, $3 \mu M$ & 320 \\
+Chloroquine, $30 \mu M$ & 320 \\
+Chloroquine, $100 \mu M$ & 160 \\
+Chloroquine, $300 \mu M$ & 160 \\
+ Methylamine, $10 \mathrm{~m} M$ & 160 \\
+ Methylamine, $30 \mathrm{mM}$ & 160 \\
+ Methylamine, $100 \mathrm{mM}$ & 160 \\
\hline
\end{tabular}

Note. Representative experiments are shown for the effects of the various inhibitors of $\alpha$-MSH pulsing of LB27.4 cells treated as described under Materials and Methods. Unpulsed or $\alpha$-MSH-pulsed $(150 \mu \mathrm{g} /$ $\mathrm{ml}$ ) and treated LB27.4 cells $\left(10^{5}\right)$ were added to $2 \times 10^{5} 27 \mathrm{E} 11 \mathrm{~T}$ cells for overnight culture, and the IL-2 titers determined as before.

ent separation of the cellular components. To calibrate the Percoll gradient to identify the membrane fractions, LB cells were incubated with ${ }^{125} \mathrm{I}$-Con A, which binds solely to the plasma membranes under these conditions, and the disrupted cell lysate sedimented over the self-forming Percoll gradient (Fig. 4A). As can be seen, the membrane-bound Con A sedimented with an apparent density of 1.045, which was highly reproducible from experiment to experiment. Unbound soluble Con A migrated at fractions 22-30, which is representative of soluble material with lower density (data not shown). Although the membrane fraction isolated by this procedure contains plasma membranes, also included are Golgi and some lysosomes, and it is therefore only representative of total cellular membrane material. However, this fractionation allowed us to determine the amount of membrane-bound and free antigen contained in the cell. We found that the total cell-associated ${ }^{125} \mathrm{I}-\alpha-\mathrm{MSH}$ following a 2- or 4-hr pulse at $37^{\circ} \mathrm{C}$, with or without monensin, or at $4^{\circ} \mathrm{C}$, was similar, but that the cellular compartmentalization was different (Figs. 4B and 4C). Thus, the amount of membrane-associated $\alpha$-MSH was reduced by $40-50 \%$ at $4{ }^{\circ} \mathrm{C}$ and by $60-70 \%$ in the presence of monensin when compared to controls. In other experiments it was found that monensin treatment of the cells after antigen pulsing did not reduce the amount of membrane-associated $\alpha$-MSH, and chloroquine treatment during the pulse also failed to reduce the amount of membrane-associated $\alpha$-MSH (data not shown). Thus, there seems to be a correlation between the amount of membrane-associated $\alpha$-MSH and the APC stimulatory capacity, and treatments that reduce stimulation likewise reduce the amount of membrane-associated antigen.

\section{What Is the Peak A Complex?}

Since the only detectable membrane-bound form of $\alpha-\mathrm{MSH}$ evident by our procedures was associated with a higher molecular weight form designated as Peak A, it 
was important to establish whether the cellular component to which $\alpha$-MSH was bound was Ia antigen. In one approach, we attempted to immunoprecipitate the Peak A from LB cell lysates following pulsing with ${ }^{125} \mathrm{I}-\alpha-\mathrm{MSH}$, as before, with the monoclonal anti-Ia antibody M5/1 14.15.2. Subsequent chromatography over Sephadex G25 showed that all the ${ }^{125} \mathrm{I} \mathrm{cpm}$ remained as Peak $\mathrm{A}$ in the cell lysate and that no $\mathrm{cpm}$ were removed by the anti-Ia antibody precipitation. However, it was possible that once Ia bound peptide, it was no longer reactive with anti-Ia antibody. For this reason, we determined whether Peak A would bind to Lens culinaris lectin, which binds Ia glycoproteins through mannose-containing carbohydrates, and would not likely be influenced by peptide binding. Again it was found that Peak A failed to bind insolubilized lectin, suggesting that if it is a glycoprotein it may not contain mannose. Both of these properties of Peak A formed with $\alpha$-MSH are similar to those we found with guinea pig cells pulsed with other peptides (6). In addition, Peak A can be formed with $\alpha$-MSH by both Ia-expressing and Ia-negative cells. Peak A derived from both of these cell types seems to be comprised of the same major acidic component(s) as determined by isoelectric focusing (22, unpublished results). Taken together, these results indicate that the majority of Peak $A$ is not Ia-bound peptide, although final confirmation of this awaits further structural characterization.

\section{DISCUSSION}

The primary reason for studying murine T-cell responses to $\alpha$-MSH was to establish a system to more carefully examine the events associated with antigen processing. In this report we present two observations on cellular processing of the peptide antigen $\alpha$-MSH for T-cell responses that are of importance for mechanisms of antigen presentation. The first is that the only detectable form of $\alpha$-MSH contained in isolated antigen-pulsed APC membranes that are directly stimulatory for T cells is as a higher molecular weight complex, and no detectable free peptide. The second observation is that in this system $\alpha$-MSH appears to require cellular processing to form the stimulatory moiety.

There seem to be several pathways by which foreign antigens may become associated with Ia antigens for $\mathrm{T}$-cell recognition. In some instances peptide antigens may directly bind to Ia molecules, as recent evidence suggests $(4,5)$. In other systems, peptides may initially be retained by the APC through interactions with membrane lipids $(10,11)$ or by association with specific antigen retention structures (SARS) (68 ), to provide the cellular reservoir of antigen that subsequently becomes associated with Ia. In yet another system, the peptide antigen human fibrinopeptide $B$ is recognized by a T-cell hybridoma only when added in soluble form, but not when bound by APC (23). In addition, the processing pathway varies for different APC types, in some instances to form the very same antigenic determinant recognized by $T$ cells (16).

The presentation of $\alpha$-MSH described herein seems to provide another pathway for peptide antigen processing that is different than that for peptide antigen systems described at the present time. In this system, APC handling of $\alpha$-MSH seems to involve cellular processing to form the stimulatory form. The evidence for this is as follows: (a) inhibition of $\alpha$-MSH processing by glutaraldehyde treatment; (b) ineffective antigen pulsing at low temperature; (c) inability to process $\alpha-\mathrm{MSH}$ in the pres- 


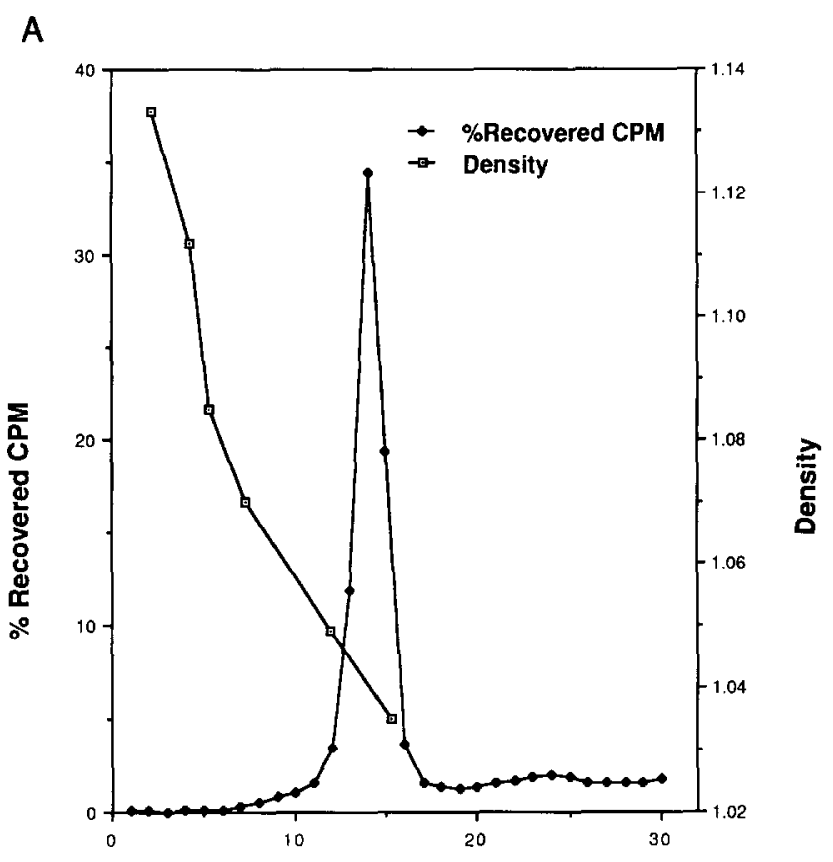

Fraction Number

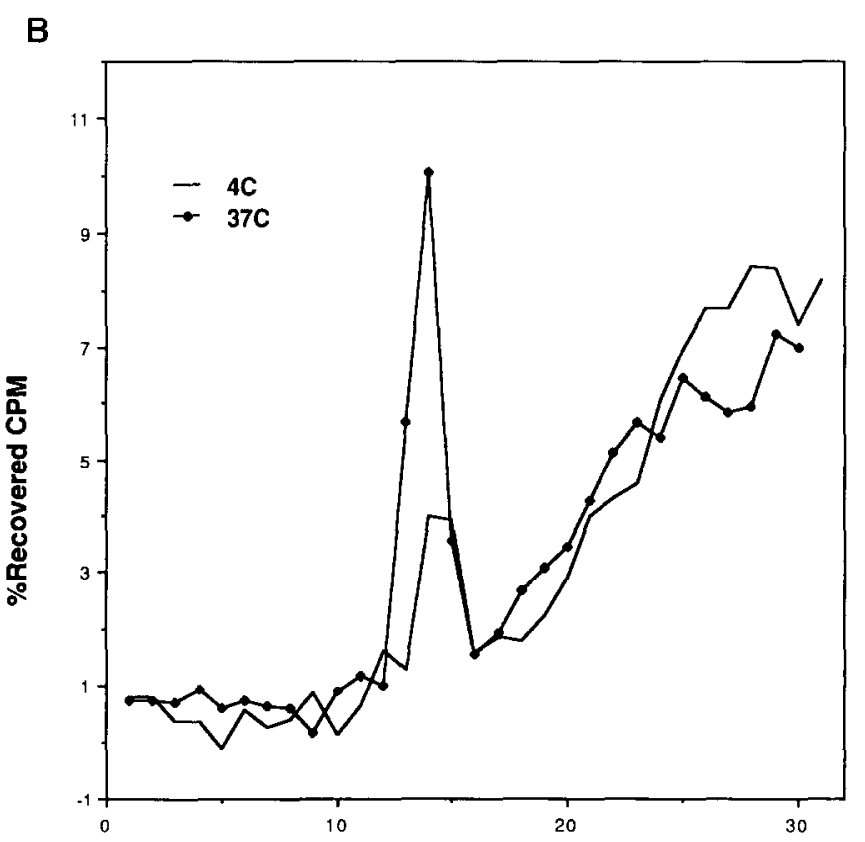

Fraction Number 


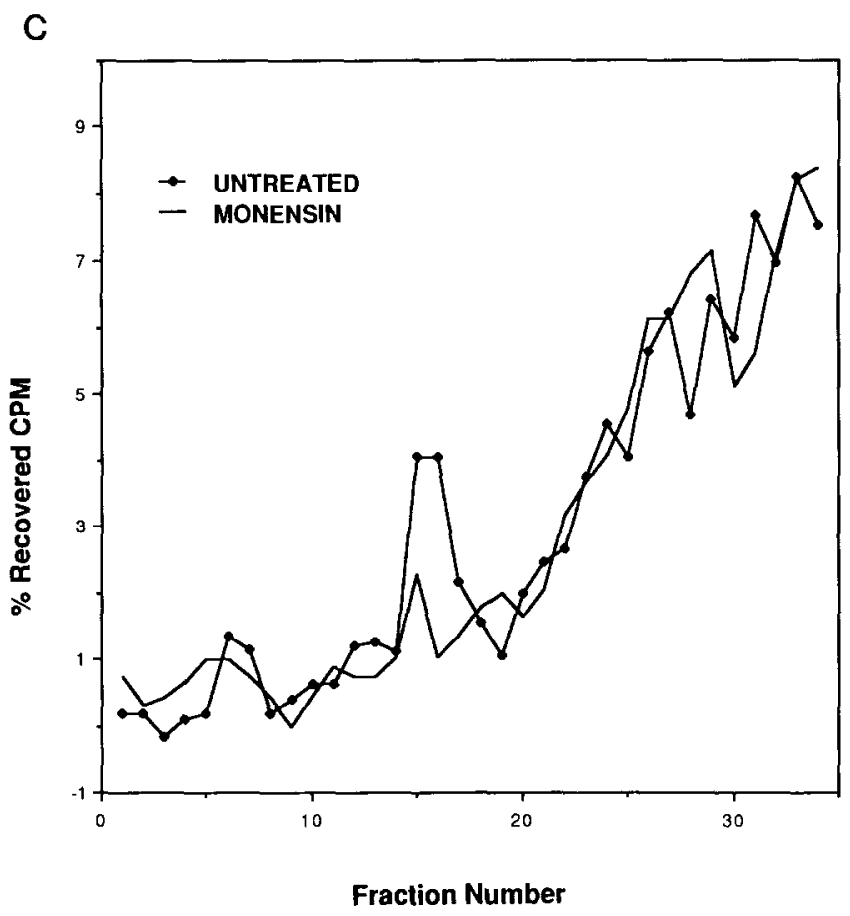

FIG. 4. Cellular compartmentalization of $\alpha$-MSH. LB27.4 cells $\left(20 \times 10^{6}\right)$ were incubated with ${ }^{125}$ I-Con $\mathrm{A}$ at $4^{\circ} \mathrm{C}$ for $30 \mathrm{~min}$, and after washing away the unbound Con $\mathrm{A}$, the cells were disrupted and the lysate sedimented over a Percoll gradient as described under Materials and Methods. In panel A is shown the density distribution in the gradient and the migration of the membrane-associated ${ }^{125}$ I-Con A. In panels B and $C$ are shown results of sedimentation of disrupted cell lysates from LB27.4 cells incubated for 2 hr at 37 or $4^{\circ} \mathrm{C}$ with ${ }^{125} \mathrm{I}-\alpha$-MSH (Panel B) or at $37^{\circ} \mathrm{C}$ in the presence or absence of $50 \mu M$ monensin (Panel C). The membrane fraction can be seen to migrate at a density of 1.045 when compared to internal standards in each experiment, and more soluble material sediments with density of less than 1.025 .

ence of monensin; and (d) the failure of la-bearing membranes from unpulsed APC to stimulate in the presence of soluble $\alpha-\mathrm{MSH}$, compared to the direct stimulatory capacity of isolated membranes from $\alpha$-MSH-pulsed APC. The most prevalent explanation for the failure of aldehyde-treated APC to process antigen is that fixation prevents antigen internalization $(1,2)$. However, this generally does not apply to peptide antigens that are presented efficiently by fixed APC. Thus, the marginal capacity of fixed APC to present $\alpha$-MSH is unique for peptide antigens investigated thus far. This could be interpreted to indicate that $\alpha$-MSH must be internalized to be stimulatory, or that some membrane reorganization is required to construct the stimulatory $\alpha$ MSH-Ia moiety which is interfered with by aldehyde treatment. In this latter case, though, any postulated membrane reorganization must need the intact cell, since isolated membranes from APC are not stimulatory; once the stimulatory moiety is formed there is no further need for the intact cell since plasma membranes from $\alpha$ MSH-pulsed APC are dircetly stimulatory. Such a mechanism is difficult to envision, and we therefore favor the former possibility that $\alpha$-MSH requires internalization to form the stimulatory moiety. 
If formation of the $\alpha$-MSH stimulatory moiety indeed requires cellular internalization, it is important to establish what processing events occur inside the cell. Again, for most protein antigens one internal event occurs in an acidic compartment, which has been interpreted to be lysosomal catabolism. Agents that raise the $\mathrm{pH}$ in these compartments, such as chloroquine, thus block antigen processing by preventing proteolysis $(2,16)$. However, such treatment has no effect on the processing and presentation of $\alpha-\mathrm{MSH}$. This suggests that lysosomal catabolism of $\alpha-\mathrm{MSH}$ is not required to form the stimulatory moiety. This is consistent with the fact that intact unaltered $\alpha$ $\mathrm{MSH}$ is needed to provide the antigenic determinant recognized by T cells; no $\alpha$ MSH fragment is antigenic. Therefore, it is unlikely that processing of $\alpha$-MSH involves catabolism to a smaller antigenic fragment. However, it is possible that the peptide undergoes some other nonproteolytic modification that is required to create an altered form of $\alpha$-MSH that actually provides the determinant recognized by $\mathrm{T}$ cells, e.g., phophorylation.

Irrespective of the precise mechanisms involved in APC handling of $\alpha-\mathrm{MSH}$, it would seem that at least some of these may be involved in association of the peptide with the APC membrane fraction. Thus, those treatments that reduce the stimulatory capacity through actions at the time of antigen exposure ( $\alpha$-MSH pulsing at $4^{\circ} \mathrm{C}$, and in the presence of monensin) also reduce the amount of detectable membraneassociated $\alpha$-MSH. Since the overall amount of $\alpha$-MSH associated with the cells under these different conditions was similar, these treatments must have some effect on $\alpha$-MSH handling other than just reducing the amount of cell-associated antigen. One possibility is that the relevant $\alpha-\mathrm{MSH}$ enters the APC by endocytosis of soluble peptide (though not blocked by cytochalasin $\mathrm{B}$, unpublished observations) and becomes membrane-associated at some subsequent step. This process would be reduced at lower temperatures and potentially also by monensin. Alternatively, the peptide may bind to some rapidly cycling binding structure that is itself membrane-bound; cycling to an exposed location would also be blocked by low temperature and possibly by monensin as well. Potentially, monensin may block formation of the membranebound $\alpha-\mathrm{MSH}$ by other effects on the cell, such as intracellular transport or effects on the Golgi complex (24), or by interference with other aspects of $\alpha$-MSH modification.

The correlation between the amount of $\alpha$-MSH associated with APC membranes and their T-cell stimulatory capacity is perhaps not surprising, since it is generally accepted that most $T$ cells recognize antigen on the APC membrane in combination with $\mathrm{MHC}$ antigens. In this regard, the only membrane-associated form of $\alpha$-MSH we could detect was as a higher molecular weight complex. It would be anticipated that this complex contains $\alpha$-MSH bound to Ia to provide the neoantigenic determinant that is actually recognized by the $T$ cell. However, as yet we have been unable to demonstrate peptide bound to Ia by our detection procedures. Thus, the correlation between stimulatory capacity and membrane-associated $\alpha$-MSH could have several explanations. One possibility is that a small undetectable amount of the Peak A complex contains $\alpha$-MSH bound to Ia, and the formation of this moiety is subject to the same influences as formation of complexes with the more predominant non-Ia constituents. Alternatively, $\alpha$-MSH may not be bound to la at this point and is simply retaincd by non-Ia structures for subsequent association with Ia. Resolution of these possibilities awaits further characterization of the products contained in the Peak A complex and their relative contribution to immune responses. 


\section{REFERENCES}

1. Shimonkevitz, R., Kappler, J., Marrack, P., and Grey, H., J. Exp. Med. 158, 303, 1983.

2. Ziegler, K., and Unanue, E., Proc. Natl. Acad. Sci. USA 79, 175, 1982.

3. Watts, T. H., Brian, A. A., Kappler, J. W., Marrack, P., and McConnell, H. M., Proc. Natl. Acad. Sci. USA 81, 7564, 1984.

4. Babbitt, B. P., Allen, P. M., Matsueda, G., Haber, E., and Unanue, E. R., Nature (London) 317, 359 , 1985.

5. Buus, S., Sette, A., Colon, S. M., Jenis, D. M., and Grey, H. M., Cell 47, 1071, 1986.

6. Nairn, R., Spengler, M. L., Hoffman, M. D., Solvay, M. J., and Thomas, D. W., J. Immunol 133, $3225,1984$.

7. Thomas, D. W., Solvay, M. J., Irani, D. N., and Nairn, R., J. Immunol. 135, 4086, 1985.

8. Thomas, D. W., J. Theor. Biol. 117, 417, 1985.

9. Lakey, E. K., Margoliash, E., and Pierce, S. K., Proc. Natl. Acad. Sci. USA 84, 1659, 1987.

10. Falo, L. D., Jr., Benacerraf, B., and Rock, K. L., Proc. Natl. Acad. Sci. USA 83, 6994, 1987.

11. Cease, K. B., Buckenmeyer, G., Berkower, I., York-Jolley, J., and Berzofsky, J. A., J. Exp. Med. 164, 1440, 1986.

12. Townsend, A. R. M., Rothbard, J., Gotch, F. M., Bahadur, G., Wraith, D., and McMichael, A., J. Cell 44, 959, 1986.

13. Maryanski, J. L., Pala, P., Corradin, G., Jordan, B. R., and Cerrotini, J.-C., Nature (London) 324, 578, 1986.

14. Germain, R. N., Nature (London) 322, 687, 1986.

15. Kappler, J. W., Skidmore, B., White, J., and Marrack, P., J. Exp. Med. 153, 1198, 1981.

16. Kim, K.-H., Solvay, M. J., and Thomas, D. W., Cell. Immunol. 96, 267, 1985.

17. Kappler, J., White, J., Wegmann, D., Mustain, E., and Marrack, P., Proc. Natl. Acad. Sci. USA 79, $3604,1982$.

18. Oi, V. T., Jones, P. P., Goding, J. W., Herzenberg, L. A., and Herzenberg, L. A., Curr. Top. Microbiol. Immunol. 81, 115, 1978.

19. Bhattacharaya, A., Dorf, M. E., and Springer, T. A. J. Immunol. 127, 2488, 1981.

20. Crumpton, M. J., and Snary, D., Contemp. Top. Mol. Immunol. 3, $27,1974$.

21. Merion, M., and Poretz, R. D., J. Supramol. Structure Cell. Biochem. 17, 337, 1981; Cell Recog., p. 433.

22. Betancourt, S. V., Solvay, M. J., Irani, D. N., Thomas, D. W., and Nairn, R., J. Immunol. in press.

23. Thomas, D. W., and Solvay, M. J., J. Immunol. 137, 3401, 1986.

24. Tartakoff, A. M., In "Methods in Enzymology" (S. Fleisher and B. Fleisher, Eds.), Vol. 98, p. 47. Academic Press, New York, 1984. 